\title{
A Case For Participatory (Cost Sharing) Approach to Agricultural Extension Delivery in Nigeria
}

Bello, M and Salau, E. S.

Department of Agricultural Economics and Extension

Nasarawa State University, Keffi

Shabu - Lafia Campus

E-mails:almu457@yahoo.com

\begin{abstract}
In Nigeria, it is the Small Scale agricultural producers that collectively sustain the nation. Privatization and Commercialization programmes in Nigeria were designed and implemented in the past towards the benefit of hand picked individuals at the expense of the resource- poor farmers who gladly relinquished their valuable parcels of land for the development of governments' projects which were privatized to these wealthy individuals. Besides, resource-poor farmers never benefited from specialized governments' programmes designed for the upliftment of the welfare of the rural poor (resource-poor farmers), including the so called subsidies on fertilizers. These existing inequalities in the nations' agricultural and rural development policies, including agricultural extension services, necessarily give the credence to the idea that, at this time of the nation's affluence, agricultural extension delivery services to resource-poor farmers should not be privatized or commercialized. Instead, this paper is recommending the participatory (cost sharing) approach to the nation's agricultural extension services as a panacea to the current effort to source for appropriate agricultural extension service for Nigeria.
\end{abstract}

\section{INTRODUCTION}

Agricultural Extension refers to an education system that provides farmers with technical advice required to increase farm output and income including advice on credit, other inputs and marketing. It also provides research institutes and credit institutions information about farmer's conditions.

Various attempts have been made in Nigeria since the colonial period to produce practical approach to inputs delivery systems to the farmers for enhanced productivity. Diverse as the approaches for the extension system were, their funding methods were substantially derived from either the national revenues or international donors. After independence, however, extension system in the country was changed to the model of Training and Visit under the Agricultural Development Programme Extension system. This system of extension does not only emphasize features of professionalism, single line of command, time-bound work and concentrated efforts; but is also costly to implement. 
Effective extension delivery system helps to narrow the communication gap between researchers who develop new technologies and the farmers who are the end users of the discoveries. Acceptance of new technologies by farmers is a necessary pre-condition for agricultural and rural development. Singh (1985) stated that linkages between research and extension are imperative. Without the two-way link the latter quickly runs out of material to extend while the former, lacking field feed back, progresses to more academic and less relevance to research work.

Successful implementation of agricultural extension activities is, however, strongly dependent on adequate and timely funding. The major agricultural extension service financiers in Nigeria currently are the Federal and State Governments, supported through loans by the World Bank, International Fund for Agricultural Development (IFAD), and the African Development Bank (ADB) (Ogunbameru, 2005).

In recent years the Nigeria Agricultural Extension Service has been experiencing dwindling funding from the governments. (Zaria et al; 1995, Ogunbameru, 1996; Okoro, 2000). This is very apparent in the sliding performances of the state wide ADPs. Consequently many writers have advocated for various alternative funding systems for agricultural extension service in Nigeria and other developing Nations.

Worldwide, the public sector plays a dominant role in the provision of agricultural extension services. According to a survey conducted by the FAO, about $81 \%$ of extension work around the world is carried out through a ministry or department of agriculture (Swanson et al., 1990). Globally, some 600,000 extension workers are engaged in the provision of extension services to farmers, of which $95 \%$ is carried out by public extension (Rivera and Cary, 1997). The public extension system is now seen as outdated, top-down, paternalistic, inflexible, subject to bureaucratic inefficiencies and therefore unable to cope with the dynamic demands of modern agriculture (Rivera et al., 2000).

The failure of public sector extension has been attributed to a number of factors including poorly motivated staff, a preponderance of non-extension duties, inadequate operational funds, lack of relevant technology, poor planning, centralized management and a general absence of accountability in the public sector (Antholt, 1994). In genera, public extension services have consistently failed to deal with the site-specific needs and problems of farmers (Ahmad, 1999). As a result of the relatively poor performance record of the public sector extension, there have been calls for the introduction of private extension services which is thought will provide more effective and efficient services to clients. However, complete privatization and commercialization of extension services in Nigeria will spell doom for the agricultural industry. This is because majority of our farmers have weak capital base to be able to pay fully for extension services. Besides, ignorance and low educational level will not permit them to engage the services of private extension agencies. It is on this basis that a participatory (cost sharing approach) is being advocated in this paper.

According to Ozor et al (2007), cost-sharing extension approach involves government-farmer partnership in the funding of agricultural extension service. It is one of the reforms aimed at achieving a sustainable funding for extension services.

The cost sharing extension approach assumes that cost-sharing with local people (who do not have the means to pay the full cost) will promote a programme that is more likely to meet local situations and where extension agents are more accountable to local interests. Its purpose is to provide advice and information to facilitate farmers' self-improvement. Success of the approach is often measured by the willingness of the farmers to pay for the services (Francais, 2001). 


\section{Journal of Agricultural Extension}

Vol. 13 (1) June, 2009

As a participatory methodology cost-sharing will promote innovation ownership, increase adoption rate and acceptability of new technologies. It will also enhance linkages between the various actors such as the researchers, farmers, extensionist and the input providers and increase learning from each other (Sinkaiye, 2005).

\section{The Need for adequate and timely funding of Agricultural Extension Service}

In Nigeria ADPs serve as the conduit between agricultural research institutions and the farmers. While these research institutes continue to generate relevant, appropriate and affordable technologies, the capacity of extension organizations to effectively transfer the technologies to end-users (farmers) has been impaired by inadequate and uncertain funding (Shaib et.al, 1997; Okoro, 2000). The resultant effects of poor funding of agricultural extension are mass retrenchment of field extension workers, stagnation of both field and supervisory work, low morale of staff, a wide gap between agricultural technology generation and technology adoption, decreased agricultural production, among others (Ogunbameru, 2005). To revamp this trend the hands of all the stakeholders including government and private agencies, as well as farmers must be on deck to co-finance extension services in Nigeria.

Apart from the critical problem of under funding of agricultural extension services, Meludu and Idio (2004) noted that even the little fund allocated to extension is more often mismanaged and misappropriated. There is also the problem of erratic and haphazard releases of funds whereas the agricultural activities of the extension clientele (farmers) are time specific. Thus, the untimely and erratic release of the inadequate funds adversely affects the overall performance of agricultural extension services.

\section{Privatization and Commercialization of extension services in Nigeria}

Privatization of agricultural extension in the broadest sense refers to the introduction or increasing private sector participation without necessarily transferring designated state owned assets to the private sector (Rivera and Cary, 1997).

The Concept of Privatization refers to the disengagement of government activities from publicly run enterprises. It is usually linked with the sale or disposal of state assets or shares in public enterprises. The sale may for practical purpose involve all or some of the equity interest of an enterprise. In addition, it also involves the introduction of private capital management or management enterprise into a public sector activity. Hence, the word privatization has been used in both narrow and broad perspective in the context of a sale or transfer of public sector activities to private sector. Odii (2001) defines privatization as the transfer through sale of public assets or enterprises to the private sector. Privatization in a broad sense refers to not only the sales of state assets or equity interests but involve, also, any or a combination of the following (Otobo, 1998):

(i) Privatizing the management of state activities through contracts leases and concessions. Management contracts may involve the use of management enterprise from the private sector to manage government entities through payment of a fee. A private management contact is often used to strengthen unsuccessful enterprises whose tomorrow seems feasible;

(ii) Contracting out to the private sector of activities that were previously done by the state such as contracting out of tax collection to private consultants by some state governments in Nigeria;

(iii) Allowing private sector operators to compete in sectors that have been the inclusive domain of public enterprise. 
(iv) Building - Operating - Transferring (BOT) or Build - Own - Operate (BOO) system. This is one method used for new projects which are normally undertaken by public sector such as infrastructural projects and public facilities like roads, water, amongst others. Under this method the public facility concerned is built by the private sector using their own finances and is run by them under a period called the concession period;

(v) Transfer of a state department entity or statutory body to the private sector on lease concession.

(vi) Breaking of monopoly into various branches to stimulate competition.

In theory, private extension is simply the provision of a service or advice by a private firm in exchange for a fee, and the items and conditions of the transaction are negotiated in an open market (Chapman and Tripp, 2003). The privatization policy is aimed at reducing public sectors pending by handing over to the private sectors to take over (Ferrington, 1994).

Chapman and Tripp (2003) observed that privatization of extension service will only be effective if there are well trained personnel who are willing and able to respond to farmers' requirements; considerable public sector investment in education and training. Similarly, farmers need increased capacity to be able to contract; manage and evaluate private extension provision. This capacity may be enhanced through appropriate farmers' associations and through decentralized political structures.

Although several advantages have been advanced by proponents of agricultural extension privatization (Katz, 2002), the present socio-economic conditions of the farmers are such that they cannot afford private extension services. This forms the basis of an advocacy for a participatory cost-sharing approach to extension delivery.

\section{Constraints to Privatization and Commercialization of Agricultural Extension in Nigeria}

There are a number of critical factors we consider as militating against the full blown implementation of privatization and commercialization of agricultural extension services in Nigeria. These include the following:

(i) Prevailing unfavourable economic environment within the national economy: Apparent misgivings about private agencies from primary stakeholders (farmers); and usual government administrative bureaucracy.

(ii) Majority of Nigerian farmers are engaged in subsistence farming activity and employ rudimentary implements or low technology. Privatization will not benefit such farmers. This agrees with the findings of Olayide and Heady (1982) that majority of Nigerian farmers are usually small scale farmers.

(iii) Assessing monetary value to the extension services is another critical constraint in the implementation of privatization and commercialization of agricultural extension in the country. Rivera and Cary (1997) identified one of the most important constraints of introducing privatization and commercial programme in agricultural extension as the difficulty in collecting user fees and establishing cost-accounting procedures to set charges at appropriate levels. 
(iv) Also institutional restructuring is a critical constraint in the implementation of privatization and commercialization of agricultural extension services. This is due to the fact that commercialized enterprises usually raise fear of lay offs and job losses among the staff as a result of the need to make profit and remain in business which may demand private enterprise providers to focus more attention on large scale farmers likely to have resources needed to pay for the services offered. Furthermore, clients' needs not likely to yield desired return may be ignored.

(v) Another constraint is the bureaucratic bottleneck through government administrative process. Delays in bureaucratic procedures usually limit progress in the implementation of privatization and commercialization programme. This may be partly as a result of nonpreparation of the government for any difficulties in programme implementation (Odii, 2001).

It is pertinent to note that privatization and commercialization of agricultural extension requires the creation of regulatory legal framework that would promote contestable markets and protect public interest. Effective and efficient regulatory legal framework would ensure good monitoring and client's rights. Such conditions are lacking in Nigeria at present making it difficult to commence full scale privatization and commercialization of extension service.

\section{Alternative Financing Mechanism for Extension Service in Nigeria}

The private goods element of many extension services has raised interest in privatizing extension services in Nigeria. But due to the aforementioned constraints such full privatization is not feasible in Nigeria for now. In the alternative, a contracting/cost sharing approach could be another approach for consideration. Contracting strategies for extension services take many approaches to the division of responsibilities for financing, procurements, and delivery of services, though most reforms involve public funding for private service delivery (Rivera et al., 2000). The World Bank (2005) noted that contracting extension services promotes institutional pluralism, accountability to clients and efficiency in operations.

Contracting directly by farmers introduces fundamental changes in relationship. Public financing of contracted extension and information services represents an investment in public goods knowledge for small holders, as well as support for development of a pluralistic extension system and extension services marketing (fig. 1) 
Figure 1: Alternative Financing Mechanism for Extension Services:

(a) Traditional financing systems - Extension accountable to financier.

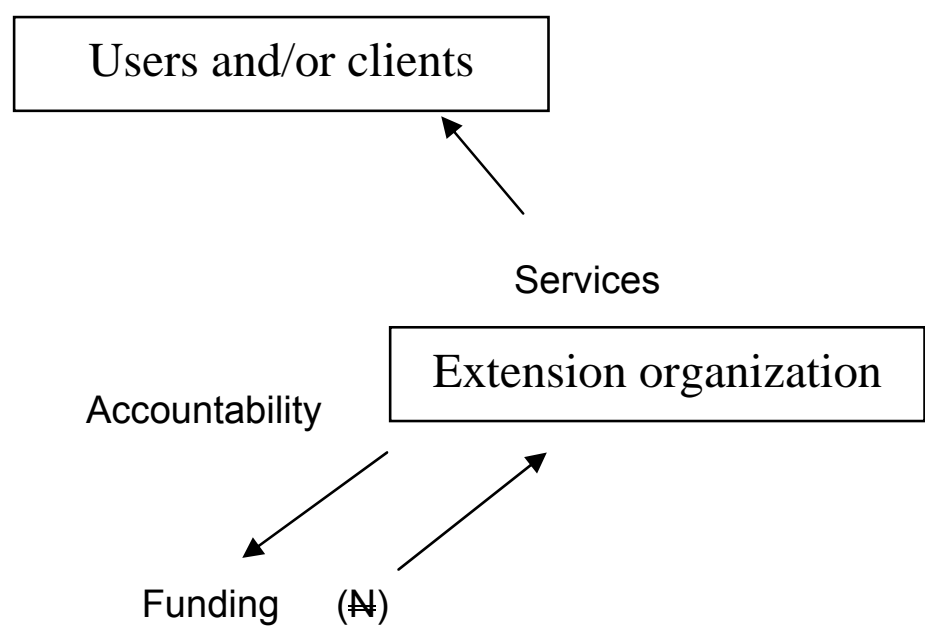

Sources of Public Finance

(b) New financing systems - Extension accountable to financier

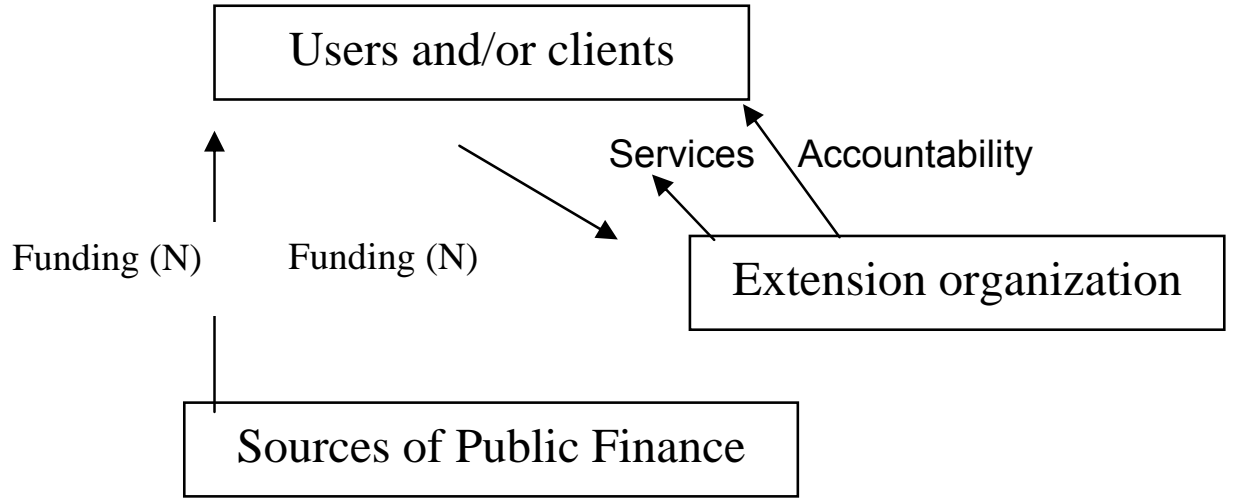

Source: Adapted from World Bank (2005)

Cost recovery/sharing mechanism is important to expand resources available for extension and to ensure that clients value the services being provided. The following mechanisms are worth considering:

(i) Introducing various co-financing arrangements: Examples are producer-controlled levy on agricultural products, fee-for-service arrangements and cost-sharing for a total programme. The World Bank (2005) observed that in this arrangement, only the large producers might be able to fully pay for services, most commercial farmers will drop out if their share of costs exceeds 50 to 65 percent of the total. For small scale farmers in developing countries like Nigeria, a cost-recovery rate of 10 to 20 percent is a reasonable initial target. 
(ii) Accessing other sources of funding: Diversifying the funding base enhances financial sustainability of public extension programmes. Alternative source might include NGOs, produce dealers, input distributors, agro industrialists and environmentalists. These important stakeholders in the agricultural industry can contribute to extension funding for their overall benefits.

(iii) Increasing client's participation: Participatory extension intensifies and improves interaction between farmers and extension agents. In this case extension agents serve as facilitators assisting the farmers to develop skills, while farmers' indigenous knowledge is tapped and incorporated into extension programmes.

\section{Future Direction of Agricultural Extension in Nigeria}

The future direction of Agricultural Extension in Nigeria should focus on the following:

(1) Prioritize target groups and areas and plan differential programme approaches appropriate to their needs and opportunities.

(2) Integrate public and private sector activities and traditional and modern communications technologies.

(3) Plan activities at a level of sophistication and intensity supportable with available human resources.

(4) Maximize cost recovery and farmer ownership of extension programmes.

(5) Ensure that technology generation/adaptation and information support services are in place.

(6) Incorporate plans for staff training in technical, economic, social and communications skills.

(7) Accept that extension programme formats are not permanent but must change in response to circumstances.

(8) Incorporate comprehensive monitoring and evaluation (M\&E) systems (Purcell and Anderson, 1997).

The analysis of the situation will specifically consider applicability of interventions in term of the socio-economic and politico-cultural milieu of farmers, organizational capabilities, communication abilities, literacy skills, leadership abilities, needs privatization, farmers' experimentation and gender. These interventions are represented schematically in Figure 2. The central unit of analysis in the framework is a farming group (male and female) charged with performing all or part of the extension task. But extension partners do not exist in vacuum. Rather, they live in complex environments that affect their ability to carry out tasks effectively and efficiently. The first two levels of analysis in the framework would assess the range of factors in these complex environments that affect farmers' performance. 

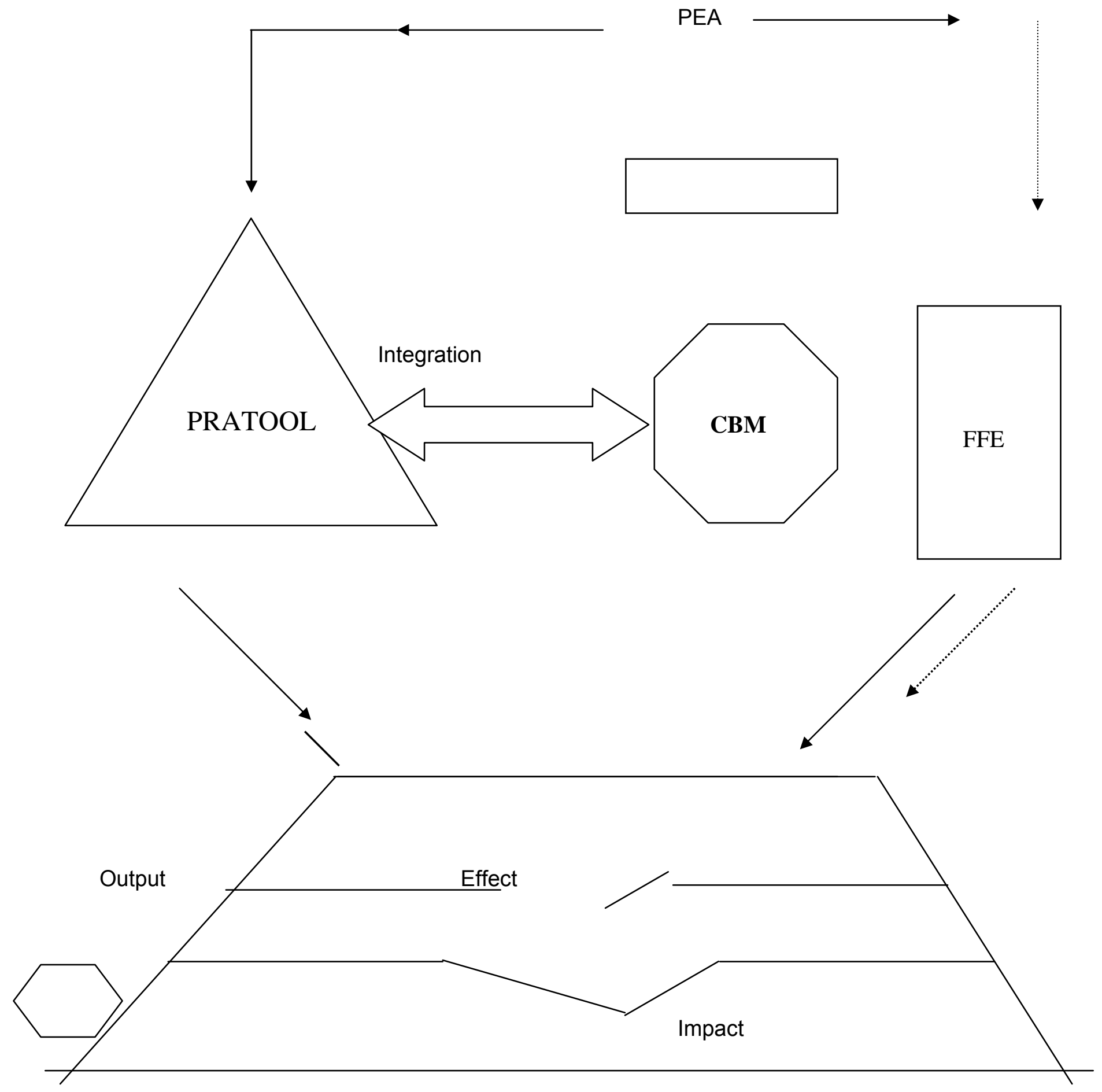

Fig. 2: Framework Model of Farmer-to-Farmer Extension

The scheme shows above all, how the behaviours of the extension partners could be rooted in and considerably influenced by the 8-dimensional capacity and capacity building structure. PEA represents Participatory Extension Approach; PRA - Participatory Rural Appraisal, FFE - 


\section{Journal of Agricultural Extension}

Vol. 13 (1) June, 2009

Farmer-to-Farmer Extension; and CBM - Capacity Building Mechanism. Eight dimensions, and correspondingly, eight levels of analysis, that affect capacity and capacity building interventions. The unbroken lines from PEA to FFE implies that the application of PEA usually lead to FFE and invariably output. Also the use of PRA tool could lead to output. However, the effective integration of CBM will lead to a more effective FFE and better output which will lead to effect and impact in the long run.

In view of the present inequity in the income and educational disparities between rural and urban sectors in the nation's economic and social infrastructure, privatization and commercialization of agricultural extension system should not be substituted for public extension delivery system. Private extension system should play a complementary role so that the sectors of farming population secure the required support at the right time and in right form. This way, sustainability of the nation's agricultural extension would not only be assured but its effects would help to enhance the productivity and the agricultural production sector of the nation.

\section{CONCLUSION}

Experiences in Nigeria portray difficulties ahead in changing policy direction of the prevailing extension approach. Existing difficulties of farmers in accepting full programme of privatization and commercialization of agricultural extension in Nigeria is not unconnected with the unacceptable level of poverty and poor educational background they find themselves in. The Nigerian small scale farmers should be educated to understand the reasons why they should contribute their share in the cost of extension delivery system in the country, in spite of the prevailing national affluence. Continuous education of the farmers on the cost-sharing extension approach and its benefits coupled with the necessary legislation will ensure the adoption of strategy. This will enhance effective and efficient extension service delivery in Nigeria.

\section{RECOMMENDATIONS}

In view of the foregoing, this paper recommends that the nations' policy makers should come to grip with prevailing national income and educational inequality through effective implementation of the governments' poverty-eradication strategies and to improve on the existing mismanagement of its macro-economic policy and provision of poor infrastructural facilities to the rural area. The country's educational system should be substantially improved to raise the literacy level with the view to eliminating obstacle in the development of the poor.

\section{REFERENCES}

Ahmad, M. (1999). Comparative analysis of the effectiveness of agricultural extension work by public and private sectors in Punjab. Ph.D. Thesis University of New England, Armidale, NSW.

Antholt, C.H. (1994) Getting ready for the 21st Century Technical Change and Constitutional Modernization in Agriculture. World Bank Technical Paper. No. 217. Washington D.C. The World Bank.

Chapman, R. and Tripe,R. (2003). Changing incentives for Agricultural Research and Extension Network. Overseas Development INsitute, London, U.R.

Ellah, F. J. (1982). Concept of Equity in Agricultural Development. An Address 
Presented at the 23rd Annual Conference of the Agricultural Society of Nigeria held at Nsukka, 1987. 10p.

Ferrington, J. (1994). Public Sector Agricultural Extension: Is there life after structural Adjustment? Natural Reserve Perspective No. 2. London Overseas Development Institution.

Francais, E. (2001) Forestry extension. http://www.fao.org/docrep/v9122E/v9122e02d. htm. Downloaded 4/11/2009.

Idris, J. (1992). The State of World Rural Poverty, Rome, Art Grafichs Fratelli

Palombi. In Rural Sociology. An African Perspective by Ignatius N Aguene. Prize Publishers, 1998 Nsukka in association with Acena Ventures Limited, Enugu.

Katz E. (2002). Financial Participation in Practice. Berater Inner News. 1/2002: 16-23.

Meludu N.T and Idio, A.A. (2004) Options for sustainable Finding of Agricultural Research and Extension for small scale farmers in a deregulated economy. Paper presented at the Agricultural Extension Society Conference at O.A.U. Ife

Odii, M. A. C. A. (2001). Problems and Prospects of Privatization of Public enterprises in Nigeria. In Co-orientation Analysis of Extension Professionals and Farmers' Perception on Privatization and Commercialization of Agriculture extension services in Delta State, Nigeria. Unpublished Ph.D. Research Findings Seminar by Ajieh, Patrick Chuks. University of Nsukka, Nigeria. 2008.

Ogunbameru, B.O (1996). The Role of Government Policy in Sustaining Research Extension. Linkage in a Dwindling Economy. Invited Lead Proper presented at the middle belt Onfarm Adaptive Research/Extension Workshop held at Minna, Niger State. February, 1996.

Ogunbameru, B.O. (2005) Funding Agricultural Extension Services in Nigeria. In: Adedoyin S.F. (Ed) Agricultural Extension in Nigeria. AESON Elami. Pp 177-181.

Ogungbile, A. O. and Olukosi, J. O. (1991). An overview of Problems of the Resource-Poor Farmers in Nigerian Agriculture. In Appropriate Agricultural Technologies for ResourcesPoor farmers. J. O. Olukosi, Ogungbile and Kalu, B. A. (eds). The Nigerian National Farming Systems Research Network. NAERLS, Zaria. 21-32pp.

Okoro F. (2000). Sustaining Agricultural Extension Service through private participation. Issues and policy implication. In: Nwosu, A.C. Nwajiuba, C.U. Industrial Enterprises Ltd. Owerri. Pp 89- 94.

Olayide, S. O. and Heady, E. O. (1982). Introduction to Agricultural Production Economics. Ibadan University, Press, University of Ibadan, Ibadan, Nigeria.

Otobo, E. E. (1988): Privatization and regulation in Africa - survey policy issues DPMN Bulletin, Vol. 5(1): $3-13$.

Ozor, N.; Agwu, A.E.; Chukwuone, NA.; Madukwe, M.C. and Garforth, C.J. (2007). Cost-sharing of Agricultural Technology Transfer in Nigeria: Perceptions of Farmers and Extension Professionals. The Journal of Agricultural Education and Extension. Vol. 13, Issue 1: 2337. 


\section{Journal of Agricultural Extension}

\section{Vol. 13 (1) June, 2009}

Purcell, D. I. and Anderson J. R. (1997): Agricultural Research and Extension: Achievements and problems in National Systems. World Bank Operations Evaluations Study. Washington, D. C. World Bank.

Rivera, W.M. and Cary, J.W. (1997). Privatizing Agricultural Extension. In: B.E. Swanson, R.P. Bentz and A.J. Sofranko (eds). Improving Agricultural Extension. A Reference Manual, Rome, FAO: 203-211.

Rivera, W; Zijp, W. and Gary, A. (2000). Contracting for extension: Review of emerging practices. Akis Good Practice Notes, Agricultural Knowledge Information System (AKIS). Thematic Group. Washington D.C. World Bank.

Shaib, B; Aliyu A. and Bakshi, J.S. (1997) Nigeria National Agricultural Research Strategy Plan. 1996-2010. Department of Agricultural Sciences, Federal Ministry of Agriculture, Abuja.

Singh, D. S. (1985). Research Extension Linkages. Managing Agricultural Extension in Nigeria. Proceedings of the National Workshop on Agricultural Extension. FACU, Regional Office, Lagos. 75 pp.

Sinkaiye, T. (2005). Agricultural Extension Participatory Methodologies and Approaches. In: Adedoyin S.F. (ed). Agricultural Extension in Nigeria. Agricultural Extension Society of Nigeria. ARMTI llorin. Pp 220-221.

Swanson, B.E; Farmor, B.J; and Behal, R. (1990). The Current Status of Agricultural Extension Worldwide. In: Swanson B.E. (Ed). Report of the Global Consultation on Agricultural Extension. Rome.

World Bank (2005) Agriculture Investment Source book. Agriculture and Rural Development. World Bank, Washington D.C.

Zaria, M.B; Arokoyo, J.O; Omotayo, A.M and Akpoko, J.G (1995) Extension Issues and Priorities from a multi sectoral perspective. In: Afolayan, S.O. and Akinbode, I.A (eds) Proceedings of the Inaugural Conference of the Agricultural Extension Society of Nigeria, held at O.A.U. Ife. 